\title{
Formation of a State Support Program for Agricultural Producers in Ukraine Considering World Experience
}

\author{
Assoc. Prof., PhD Lyudmila Pronko ${ }^{1}$, Assoc. Prof., PhD Irina Furman ${ }^{1}$, \\ Assoc. Prof., PhD Anatolii Kucher ${ }^{2}$, Yaroslav Gontaruk ${ }^{1}$
}

\begin{abstract}
In our paper we researched the state regulation in agriculture of Ukraine, as well as world experience in this field. The distribution of state financing for support of agricultural production is analyzed. We singled out the direction of state support to the agrarian sector of Ukraine. The directions of organizational reforming of households in the market conditions are investigated. The variants of integration of households of the population into more consolidated economic forms are offered. The priority of the development of cooperatives in agriculture has been argued. The positive experience of state support of servicing cooperation is considered on the example of «The Benefits of the Development of Personal Peasant, Farmers, Cooperative Movement in the Village and Advice Service for 2016-2020» of the Vinnytsia Region. The prospects of creation of cooperatives for the provision of oilseeds processing services for the energy needs of agribusinesses and provision of livestock feed with forages are argued. The prospects for realization of the program of development of agricultural servicing cooperatives within the boundaries of Ukraine are outlined.
\end{abstract}

Keywords: agrarian policy, agribusiness development program, agricultural servicing cooperative agriculture, cooperation, food safety, energy security, enterprise-agro producer, integration of farms, state support of agrarian sector

\section{Introduction}

The formulation of reasoned proposals to improve the state support of domestic agricultural producers involves a thorough study of international experience, especially in those countries in which agriculture plays a great role. Given the priority development of the agrarian sector of the economy of the European Union and the significant amount of public funding, there is an urgent need for a detailed understanding of the EU's state support mechanism for agriculture.

The agrarian sector of Ukraine's economy plays a significant role in the development of the national economy in the context of the spread globalization and integration processes. From its development, food security, economic growth and the position of the state in the world market of agrarian products depend on it. Obviously, Ukraine as a powerful producer of many types of agricultural products and an active and significant participant in world food markets will not be able to remain outside the integration processes.

The results of a theoretical analysis showed that Ukrainian scientists are exploring such aspects of the affected problem: impact of state support, credit and investment resources on the productivity of agricultural enterprises [1,2]; the current state and strategic 
priorities and financial support of Ukrainian agricultural sector development [3, 4]; system of institutional and investment support for sustainable development financing and rural areas development [5, 6]; assessment of the efficiency of resource potential employment by the communities [7]; the modern contribution of the basic categories of producers to Ukrainian agrarian production and theoretical basis of managing of enterprises' financial potential on the basis of anti-crisis management [8, 9]; effectiveness of the government regulation of the system of financial support for the development of consumer cooperation, cooperative marketing in agribusiness [10, 11] and other [12]. Foreign scientists mainly study the effectiveness of distribution and use of agricultural subsidies in different countries of the world [13-18].

\section{Materials and Methods}

The purpose of the article is to analyze the distribution of state financing for support of agricultural production in Ukraine, as well as world experience in the state regulation in agriculture; to determine the directions of organizational reforming of households in the market conditions.

The basis for conducting analytical studies in relation to the issues of the article was the following: normative and legal acts concerning the state regulation of the agrarian sphere; statistics of the Ministry of Agrarian Policy and Food of Ukraine [19, 20], State Statistics Service of Ukraine [21, 22], Vinnytsia Region State Administration [23, 24], Agrarian Union of Ukraine [25]; scientific works of scientists concerning the state of financial provision of agricultural enterprises and the functioning of the organizational and economic mechanism of regulation of the consumer goods market.

The methodological basis of the study consists of normative provisions regarding the state regulation of the agrarian sphere and functioning of the food market, which reveal the processes of functioning of the mechanisms of regulation of the agrarian sphere and substantiate the specifics of the development of forms of farming in the countryside. The solving of the tasks set in the work is carried out from the standpoint of the system approach and using the following research methods: monographic - for studying and generalizing the scientific and methodological foundations of the functioning of the mechanisms of state support of agriculture; abstract-logical - with the refinement of categorical apparatus subjects research; statistical analysis - to characterize the volumes of state financing of the agrarian sector, taking into account the role and significance of personal peasant farms; comparison - in analyzing the general state of the cooperative movement in the agrarian sector for comparison with other forms of management in the agroindustrial complex.

\section{Results}

After Ukraine's accession to the WTO, issues of structural adjustment of the national economy, in particular, raising the level of production and management standards in the agro-food sector, and establishing new effective mechanisms for state support of national agricultural commodity producers, are becoming increasingly relevant. 
State regulation of the agricultural market abroad is a complex mechanism consisting of instruments of influence on the income of peasants, agricultural production structure, agrarian and food markets, social structure of rural areas, inter-branch and inter-farm relations for the formation of optimal economic, legal and socio-ecological the conditions of development of the agricultural sector, meeting needs of the population in food products at affordable prices.

However, many questions regarding the possible adaptation in Ukraine of world-wide experience in regulating the agrarian market, improving the direction and increasing the effectiveness of state influence on the development of the national agrarian sector in the context of globalization and Ukraine's accession to the World Trade Organization remain inadequately investigated and require in-depth study.

A system of direct and indirect levers of state influence is used to stabilize agricultural production and increase the efficiency of functioning of the agrarian market in foreign countries: regulation of prices and farm incomes, budget financing, lending, taxation, stabilization of agricultural products market, etc.

At the same time practically all Western countries in the relations of agriculture with other branches, in matters of export and import of agricultural raw materials adhere to the principle of agrarian protectionism. Moreover, the success of agriculture in Western Europe, the United States, Canada, Japan, and China is bound not so much by the development of market relations in these countries, but by the limitation of the actions of market mechanisms of self-regulation using external levers of influence. This is state support to agriculture through subsidies, prices, quotas, credit and tax policies, etc.

In the middle of the twentieth century, when the main task of the agrarian sector of developed Western countries was the growth of production volumes, targeted state subsidies for the construction, purchase of equipment, and cheapening of loans became widespread. However, as the market saturation and overproduction of agrarian production has decreased, the amount of direct government subsidies has decreased. The only exception is the order of preferential agrarian lending and support to young farmers. The practice of agrarian business in recent years, in particular in the EU countries, testifies to a new tendency to reduce the total amount of economic support for agriculture. However, since 1962, when the Uniform Agricultural Policy (UAP) of the European Union countries was developed, farmers receive direct payments from the EU budget to support market prices, payments depending on the volume of agricultural production, the size of the sown area, the number of animals, targeted use of subsidies. Thanks to the implementation of the above measures, the food program in the EU countries has been successfully implemented, and European citizens have been providing food at affordable prices and living standards for rural producers.

Consequently, according to the practice of developed Western countries, the efficient development of agricultural production and rural development depend on regulation and assistance from the state.

At the moment, state support for agricultural producers in Ukraine is in a state of market transformation and accordingly has its positive and negative sides.

The main instruments of state support are interest-free budget loans to agricultural producers, tax exemptions, write-offs and debt restructuring, partial compensation of expenses for the purchase of agricultural machinery and equipment. 
The strategic goal of agrarian reform in Ukraine was not legally defined from the outset, reformation was taking place without an appropriate strategy and program. Taking into account important public functions of agriculture, three equally high priority strategic objectives of agrarian transformations in Ukraine were identified and fully grounded:

1) ensuring food security of the country;

2) the formation of a sustainable, efficient, export-oriented agriculture, based on competitive advantages;

3) the development of rural areas, and in the long term - the formation of a middle class in the countryside.

Such an integrated approach was the basis of the State Target Program for the Development of the Agrarian Sector for the Period until 2020 [26]. The purpose of the Program is to create organizational and economic conditions for the effective socially oriented development of the agrarian sector of Ukraine's economy and increase its competitiveness through efficient use of natural and human resources, stimulation of the development of small and medium-sized producers, as well as rural families for commodity agricultural production, producers' education, equality all commodity producers in access to financial resources, improvement of forms and methods of state support, its transparency, predictability and consistency [26].

Each year, the state budget law defines the types of state targeted programs in support of agro-industrial enterprises and the amount of expenditures on them. The distribution of expenditures for state aid for the development of the agrarian sector during 2016-2017 is shown in Table 1.

Table 1: Distribution of state funds to support agricultural production in 2018 (thsd UAH)

\begin{tabular}{|l|c|c|c|}
\hline $\begin{array}{l}\text { Name in accordance with departmental and program classification } \\
\text { of expenditures and lending to the state budget }\end{array}$ & $\begin{array}{c}\text { General } \\
\text { fund }\end{array}$ & $\begin{array}{c}\text { Special } \\
\text { fund }\end{array}$ & Total \\
\hline $\begin{array}{l}\text { Financial support of measures by cheapening of loans } \\
\text { Research, applied scientific and scientific and technical } \\
\text { developments, works on state target programs and government } \\
\text { orders in the field of development of the agro-industrial complex, } \\
\text { training of scientific personnel, scientific developments in the field } \\
\text { of standardization and certification of agricultural products, } \\
\text { research and experimental development in the field of agro- } \\
\text { industrial complex }\end{array}$ & 77561.5 & 55083.9 & 132644.9 \\
\hline $\begin{array}{l}\text { Financial support of measures in the agro-industrial complex } \\
\text { The expenditures of the agrarian fund are related to the complex } \\
\text { of measures for storage, transportation, processing and export of } \\
\text { objects of state price regulation of the state intervention fund }\end{array}$ & 0.0 & 52200.0 & 52200.0 \\
\hline $\begin{array}{l}\text { State support for the development of hops, the laying of young } \\
\text { gardens, vineyards and berries and their supervision }\end{array}$ & 300000.0 & 0.0 & 300000.0 \\
\hline State support of livestock sector & 4000000.0 & 0.0 & 4000000.0 \\
\hline Financial support of agricultural producers & 945000.0 & 0.0 & 945000.0 \\
\hline Financial support of farms & 1000000.0 & 0.0 & 1000000.0 \\
\hline
\end{tabular}

Source: developed by authors using data from Ministry of Agrarian Policy and Food of Ukraine (2018): Government Support to Agriculture: Governmental Programs [20]. 
As we can see from Table 1 in the State Budget-2018, to finance expenditures of the Ministry of Agrarian Policy and Food, including expenditures on state support of agricultural producers, more than 14.1 billion UAH are envisaged. For comparison, last year, almost 9.5 million UAH were allocated for these needs. Moreover, as in previous years, support can be provided both on irrevocable and on a turning (granting of credits) basis.

As we see from Table 1, in 2018, the state allocated about UAH 3098 billion, which is $81 \%$ less than in 2016. The tables show that in 2017 state funds for support of agricultural production were provided in the form loans to farms and financial support of measures in the agro-industrial complex on terms of financial leasing.

Therefore, in order for agricultural production to develop more effectively and to increase its competitiveness, it is first necessary to adjust the process of providing state financial support to agricultural producers, to ensure its increase and effective use, in accordance with the principles of a market economy and approaches to state encouragement of agricultural production in other countries.

The settlement also requires a system of direct state aid to the agrarian sector. Donations and reimbursements from the state budget should be paid primarily to agricultural producers, and the main part of the funds should be directed towards financial support for programs that are capable of ensuring the sustainable development of the agrarian sector.

In the state budget - 2018 to finance expenditures of the Ministry of Agrarian Policy, including expenditures for state support of agricultural producers, provided more than 14.1 billion UAH. For comparison: last year about 9.5 million UAH were allocated for these needs.

The agrarian sector is one of the most powerful branches of the economy, which brings a lion's share of revenues to the budget and contributes to the improvement of the economic situation in the state. In most developed countries, the state provides a great deal of support to agricultural producers, and Ukraine is no exception.

In our country there are several budget programs aimed at supporting the agrarian sector, in particular, "Financial support of measures in the agro-industrial complex through cheapening of loans». The Resolution of the Cabinet of Ministers of Ukraine dated 01.03.2017 № 130 [27] approved the Procedure for using the funds provided for in the state budget for partial compensation of the cost of agricultural machinery and equipment of domestic production.

In 2018, the Ministry of Agrarian Policy for Support intends to allocate 6.3 billion UAH (Table 2). It is also planned that the budget subsidy for the development of agricultural commodity producers and the stimulation of agricultural production ( 2 billion UAH) will be improved due to changes in the formula for charging funds and limiting support to one producer no more than 150 million UAH.

To finance partial compensation of the cost of purchased agricultural machinery and equipment of Ukrainian production, an increase of up to 1 billion UAH is envisaged, as in the case of a timely launch and enhanced information campaign, this program will have a multiplier effect and will ensure the development of many spheres. 
Table 2: Areas of state support to the agrarian sector of Ukraine in 2018

\begin{tabular}{|l|c|}
\hline Areas & mln UAH \\
\hline 1. Development of livestock & 4000.0 \\
\hline 2. Development of farms & 1000.0 \\
\hline 3. Lower prices for agricultural machinery & 945.0 \\
\hline 4. Development of horticulture and viticulture & 300.0 \\
\hline 5. Partial reimbursement of bank interest & 66.0 \\
\hline 6. Total & 6311.0 \\
\hline
\end{tabular}

Source: calculated by authors.

According to the program of financial support for the development of farms and rural cooperatives ( 1 billion UAH), $50 \%$ of the total amount will be provided through cooperatives, which will stimulate the development of cooperation among farmers. Other $50 \%$ will be provided to farmers of the same type as family farmers, classical farmers and those who want to become a farmer for the first time. In addition, the aid is provided for agricultural sectors such as niche crops (sorghum, chickpeas, lentils, beans, flax, hemp, etc.), horticulture, horticulture, horticulture, livestock and bioenergy.

Particular attention is paid to the livestock support program as one of the priority areas in 2018. Financial support (2 billion UAH) will be provided for the construction and reconstruction of livestock complexes, which will stimulate the growth of the number of animals and, as a result, will lead to a leveling of the price situation for meat.

Also, in 2018, it is planned to launch a program for the improvement of genetics in livestock farming (300 million UAH), in particular in three main areas: meat cattle breeding, dairy cattle breeding and pig farming.

Among the priorities of the Government and the Ministry of Agrarian Policy is the stimulation of the farmers' movement and the creation of a successful business model in Ukraine - the formation of an efficient and socially responsible rural owner.

For the development of farms and agricultural cooperatives for 2018, significant state support is expected to amount to 1 billion UAH.

Financial support is provided:

(i) for the farm:

- there are no more than 500 hectares of agricultural land in use, registered property rights and / or land use rights;

- has a net income from the sale of products (works, services) to 15 million UAH annual turnover;

- identification and registration of farm animals

(ii) agricultural service cooperative:

- at least 20 members;

- there is at least one farm in the structure;

- individuals in the use of not more than 100 hectares of agricultural land.

The main types of state support are:

- partial compensation of the cost of seed of agricultural plants of domestic breeding - is carried out in the amount of $80 \%$ of the cost of seeds, but not more than 30 thousand UAH for one farm;

- partial compensation of expenses related to the provision of agricultural advisory 
services in the following areas: agronomy, veterinary medicine, zootechnics, accounting, marketing, legal advice - is carried out in the amount of $90 \%$ of the cost, but not more than 10 thousand UAH;

- financial support of agricultural servicing cooperatives for dairy and raspberries activities for the purchase of equipment for the storage and processing of agricultural products - is provided in the amount of $70 \%$ of the cost of purchased equipment, but not more than 3 million UAH for one cooperative;

- partial compensation of the cost of purchased agricultural machinery of domestic production - is provided to farmers in the amount of $40 \%$ of the cost of purchased equipment and equipment, including:

- in the amount of $25 \%$ - due to the budget program of the CPCMC 2801580 «Financial support of agricultural producers»;

- in the amount of $15 \%$ of the cost - at the expense of the budget program of the CPCRC 281230 «Financial support for the development of farms»;

- cheapening of loans - is carried out by providing partial compensation of the interest rate on borrowed in national currency loans provided by the state form. Compensation is granted for accrued and paid in the current year interest for using loans in the amount of 1.5 discount rate of the NBU, but not higher than the amount stipulated by the loan agreement, reduced by 1 p.p.

Compensation is subject to interest rates on a loan when:

- attracted up to one year, the volume of which does not exceed 500 thousand UAH to cover production costs;

- attracted up to three years, the volume of which does not exceed 9 million UAH for the purchase of fixed assets of agricultural production, the implementation of expenses related to the construction and reconstruction of agricultural production facilities.

Significant state support is defined in the Development Program and for agricultural producers. Thus, according to the Resolution of the Cabinet of Ministers of Ukraine dated 01.03.2017, No. 130 «On Approval of the Procedure for Using the Funds Envisaged in the State Budget for Partial Compensation for the Cost of Agricultural Machinery and Domestic Production Equipments [27], it is provided for from 1.01. In 2018, a refund of $25 \%$ of the cost of purchased equipment and equipment. Partial compensation is granted for equipment and equipment, the degree of localization of which exceeds $60 \%$, except for tractors and other self-propelled power means of agricultural purpose, special agricultural vehicles, self-propelled and forage harvesters, the degree of localization of which is $45 \%$.

Up to $80 \%$ of expenditures made in the current and previous budget years, in accordance with the resolution of the Cabinet of Ministers of Ukraine dated 07.02.2018, No. 254 [28], is compensated by the state for the purchase of planting material of fruit and berry crops, grapes and hops.

Also in 2018, the CMU adopted a resolution number 254, according to which partial compensation of the interest rate on borrowed in national currency by bank loans is paid to borrowers who have net income from sales of products in the last year to 20 million $\mathrm{UAH}$. Advantage is given to borrowers involved in growing vegetables in open soil, sugar beet, gardening and berry picking.

Expected results: 
- Cheaper purchase of 5050 units of domestic agricultural machinery.

- Increase in the share of farms in the production of gross agricultural products from 6 to $10 \%$.

- Increase in cattle by $11 \%$, pigs by $18 \%$, sheep by $6 \%$.

- Cheaper maintenance of 700000 heads of cattle for the population and producers of 3100 hectares of new gardens, berries and vineyards.

- Increase of average productivity of milk cattle from 4000 liters/year to 7000-9000 liters/year.

The research has shown that the following factors influence the formation of financial resources in the agrarian sector:

- Firstly, in the agricultural sector, the main means of production are land that is not depreciated and, therefore, does not participate in the formation of the cost of production. At the same time, different levels of natural fertility and location contribute to the formation of differentiated profits (rents) from commodity producers.

- Secondly, as a part of the main productive assets, a significant place is occupied by productive and working cattle, whose reproduction is carried out directly in the industry by growing young animals. For productive cattle no depreciation is charged, its cost is not transferred to the cost of production.

- Thirdly, the essential characteristic of this industry is self-reproduction. A significant part of the products obtained is not sold to the party, but remains in the household as young, feed, manure for fertilizing fields, etc. Therefore, it is not part of the marketable products and does not accept the monetary form, but participates in domestic economic turnover.

- Fourth, the natural process of growing animals and plants determines the peculiarities of the circulation of means of agricultural producers: its comparative slowdown, the gradual increase in costs, the release of funds from the cycle simultaneously, that is, during the periods of release and sale of products.

The above factors lead to specific forms of organization of finance of agrarian commodity producers. During the year, they create a seasonal gap between the timing of spending and receiving profits. In this regard, commodity producers must have significant amounts of working capital. However, not at the expense of their own sources, since it is inappropriate, but at the expense of borrowed, including credit funds. Therefore, the organization of financial support for the activities of business entities in the agrarian sector is carried out mainly in three forms:

- self-financing, ie use of own resources;

- lending on the basis of mobilization and redistribution of temporarily free funds;

- budget financing on a non-refundable basis at the expense of state and local budgets.

Agribusiness enterprises cannot fully satisfy their own needs for financial resources on their own; therefore, the availability of enterprises to external sources of financing (mainly the availability of bank loans) is of great importance. At the expense of loans, the formation of fixed assets and working capital takes place, payments are made between commodity producers, an increase in the volume of money supply takes place, processes of actual accumulation, production and social development of agricultural enterprises are accelerated.

Bank loans, as one of the main sources of providing financial resources for agricultural 
activities of enterprises, today must play a significant role in stimulating reproductive processes in the economy. However, for the agrarian sector of the economy in the market conditions, credit relations were very complex. The crisis in the economic system has practically undermined the financial sustainability of most agrarian enterprises, resulting in a sharp decline in the number of reliable borrowers, although the need for credit as an effective source of financing for entrepreneurship has not diminished.

Consequently, the state's financial policy in the agro-industrial complex of Ukraine should be oriented on the structure of the agrarian sector of the economy, which will be self-sufficient and financially independent. Funding from budget funds should be focused on green box activities - environmental protection and food security.

But a significant disadvantage is that in the formation of new forms and types of regulation of the agrarian sphere, the dynamics of institutional transformations, first of all their regional economic, social, natural and other features, was not sufficiently taken into account.

In order to overcome the above problems, it is advisable to pursue a policy of stimulating the development of agricultural cooperatives in the countryside, which will enable the establishment of closed cycles for the production and processing of products and their implementation.

The directions of diversification of households are shown in Figure 1.

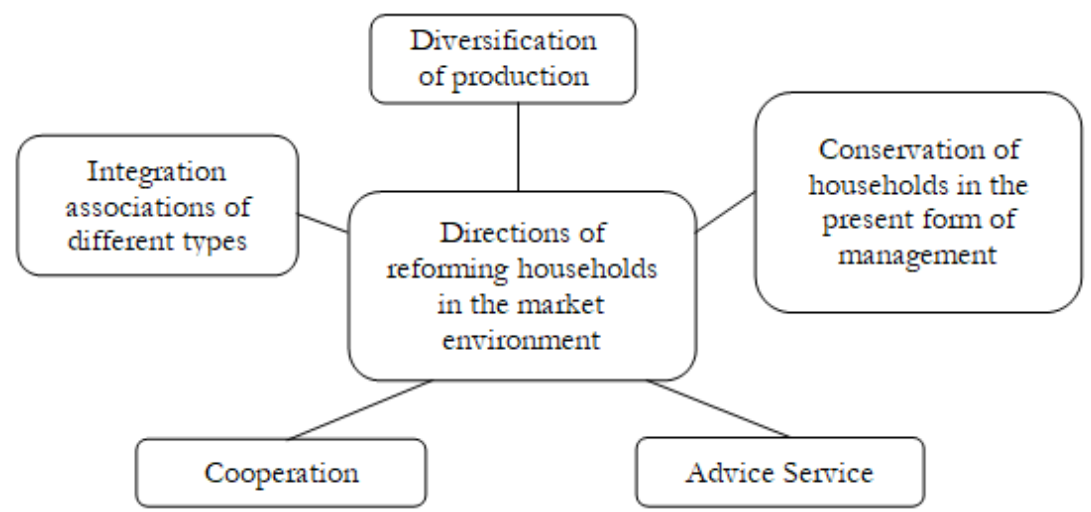

Figure 1: Directions of organizational reforming of households in the market conditions

Source: author's elaboration.

From the above-stated directions of reform it is expedient to determine the integration of economic activity, because it allows to increase the competitiveness of more integrated formations in the village within the general tendency of integration of agricultural producers.

The development of private peasant farms will give an impetus to the development of the declining livestock sector and to improve rural development.

Integration of households with agricultural enterprises into production cooperatives will allow:

- provide farmers with access to land resources and, on the basis of a higher production culture, to increase their own profitability; 
- to create the possibility of helping peasant households with material resources (seeds, fertilizers, herbicides, etc.);

- improve the implementation by peasant households of livestock products at higher prices;

- to transfer the leased peasant households with the necessary means of mechanization of production;

- to participate in the organization of production and processing of agricultural products at enterprises located in rural areas.

Types of integration associations with the participation of households are presented in Table 3.

Table 3: Options for integrating households into more economical forms

\begin{tabular}{|c|c|}
\hline \multirow{3}{*}{ 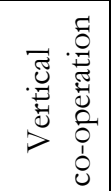 } & Households + Processing companies \\
\hline & Households of the economy + Farmers economy + Processing enterprises \\
\hline & $\begin{array}{l}\text { Households of the economy }+ \text { Farmers economy }+ \text { Agricultural enterprises }+ \\
\text { Processing enterprises }\end{array}$ \\
\hline \multirow{3}{*}{ 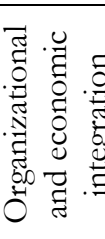 } & $\begin{array}{l}\text { Households }+ \text { Processing enterprises }+ \text { Enterprises agroservice }+ \text { Trade } \\
\text { organizations }\end{array}$ \\
\hline & $\begin{array}{l}\text { Households of the economy }+ \text { Farmers economy }+ \text { Recyclingenterprises }+ \\
\text { Enterprises agroservice }+ \text { Trade organizations }\end{array}$ \\
\hline & $\begin{array}{l}\text { Households of the economy }+ \text { Farmers economy }+ \text { Agricultural enterprises }+ \\
\text { Processing enterprises }+ \text { Enterprises agroservice }+ \text { Trade organizations }\end{array}$ \\
\hline
\end{tabular}

Source: author's elaboration.

But it should be noted that in the implementation of integration often there are difficult problems regarding the distribution of profits between participants and compliance with the rules of existing legislation. Typically, these relationships include: the observance of fairness between the members of the association; determination of the system of mutual settlements, based on the contribution of each participant, in the total profit of this integrated association; consolidation of contractual relations and inter-company interaction between the participants; problems of pricing and lending of the members of the association.

The process of integration and co-operation in the countryside is currently undergoing some difficulties. Of course, the Law of Ukraine «On Agricultural Cooperation» [29] created the prerequisites for the establishment and development of cooperation in the agrarian sector of the Ukrainian economy, but no concessional conditions for the cooperative movement were created.

Cooperation in action will promote the development of vertical ties between agrarian producers of agricultural products and sub-sectors of its further processing.

Forms of cooperation in the agrarian sector of the economy are presented in Figure 2. 


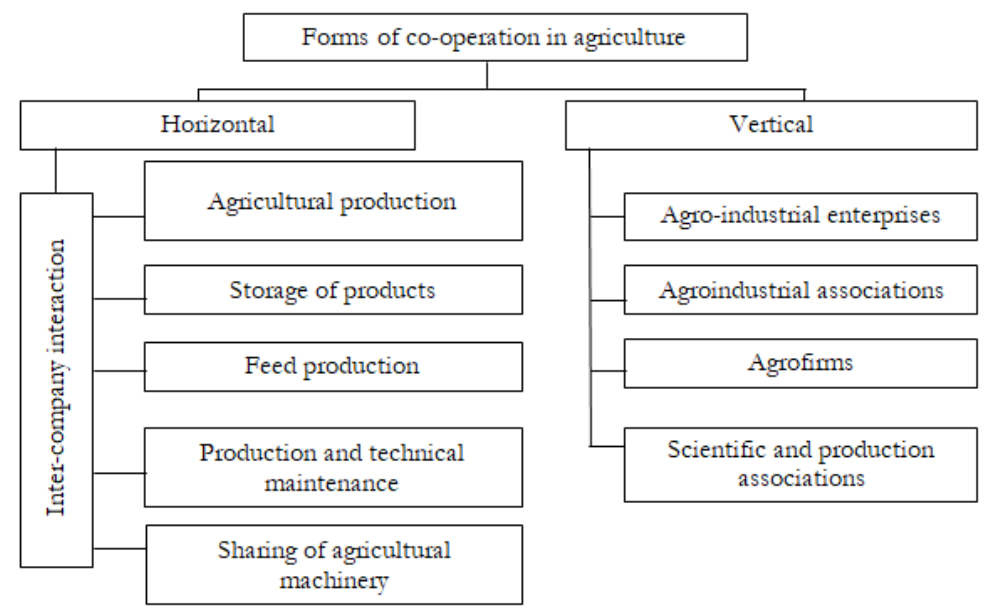

Figure 2: Forms of cooperation in the agrarian sector of the economy

Source: author's elaboration.

In the first case, when creating inter-economic formation, there is a fundamentally new legal form, which includes a voluntary unification of parts of financial, logistical and labor resources on a unit basis of the participants, while maintaining independence in the organizational and legal status of the participants. In accordance with the Commercial Code of Ukraine, such formations may at present be an economic partnership. Economic relations between the participants of the cooperation are determined by the common property in the amount corresponding to the share participation of each of them in the joint production and accordingly the profit received.

Another form of co-operation is a contract of joint activity (partnership) without the formation of a legal entity for profit. A joint venture agreement may consist of holdings for the production of predominantly one type of product (seed or feed), or in the technological stages of its production (fattening or raising animals, etc.). Economic relations of participants of this type of cooperation can be based on the share distribution of profits received as a result of their joint activities, depending on the cost of final products.

It is the development of small-scale entrepreneurship in rural areas, aimed not only at the production of alternative fuels, but also in the direct processing of agricultural raw materials, which can become a kind of «locomotive» for the development of Ukraine's economy and its transition from the production of raw materials to its processing. It is also advisable to develop a cooperative movement in the countryside to stimulate the development programs of agricultural service cooperatives (hereinafter referred to as the ASC).

The main tasks of the development of the ASC are the following:

- increase of the efficiency of agricultural production due to optimization of expenses of commodity producers for the purchase of means of production, carrying out of separate technological operations, carrying out of marketing researches, and also increase of profits from sales of products;

- promotion of the formation on the cooperative basis of the elements of the 
infrastructure of the agrarian market - agro-trading houses, procurement points, wholesale food and vegetable markets;

- creating a supportive competitive environment by supporting the development of alternative commercial structures;

- stimulation of the processes of self-organization of agricultural producers of all forms of ownership and of the rural population on cooperative principles for the organization and maintenance of agricultural work, the sharing of property, the provision of technological, social and other services;

- development and increase of efficiency of ASC, increase of incomes and a living standard of rural inhabitants;

- creation of additional workplaces in the countryside.

As a result of the project, the following benefits are achieved by the members of the ASC:

- the cost of technological services is reduced because they are provided at a price that does not exceed the cost price;

- the long-term preservation of household products is ensured and the revenue from its sale increases due to the use of seasonal price fluctuations;

- the income of households is increased from the sale of potatoes;

- there is an opportunity to additionally attract third-party financial investments under the collective guarantee of the members of the ASC;

- conditions are created for the formation of large-scale batches of products, increase of its qualitative indicators;

- new jobs are created;

- sustainable development of households is ensured.

For example, the development of service cooperatives in rural areas, in our opinion, should be taken in the «Program for the development of personal peasant farms, cooperative movement in the countryside and counseling for 2016-2020» adopted in the Vinnytsia region.

The program is aimed at supporting and developing private peasant farms in the region, farms and agricultural service cooperatives, as equal forms of farming in rural areas in the present conditions, strengthening of positive trends in their activities. Also, further development is planned in the field of infrastructure of the agrarian market of the region, advisory and rural green tourism.

The main objective is to provide adequate and stable conditions for the support of the development of agricultural service cooperatives, private peasant and farm enterprises as an important socio-economic institution for improving the efficiency of agricultural production in the region, creating additional rural jobs, active rural development and raising the level and quality of life rural population as a whole.

To date, three areas of priority are lending to farmers and private farms, partial reimbursement of the cost of purchased milking equipment and refrigeration equipment and the creation and improvement of public pastures.

Favorable loans are provided by the Regional Investment and Construction Facility. Priority directions for lending are the reconstruction of livestock buildings, the purchase of equipment for the processing of agricultural products, support of agricultural servicing cooperatives. Households can get a soft loan for 3 years at $6 \%$ per annum. Further development of cooperation in the countryside is possible by creating favorable 
conditions for the development of ASCs, which will include: financial participation in the creation of state-owned enterprises in the form of village councils, cooperative members and potential investors; creation of favorable legislation; legal support and counseling support for future members of cooperatives by local authorities (village, town councils). Now we consider use of gas oils (diesel fuel) by regions of Ukraine (Figure 3).

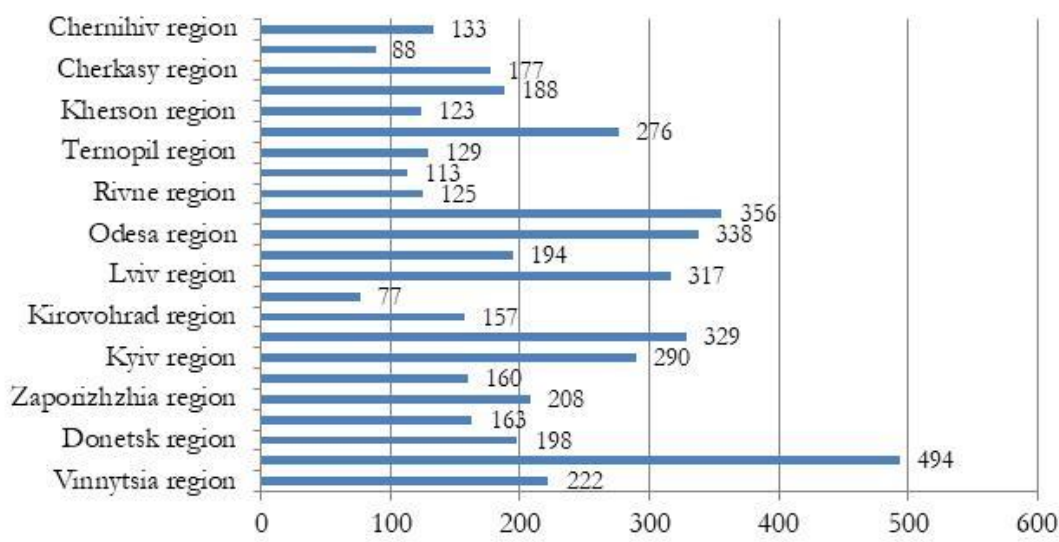

Figure 3: Use of gas oils (diesel fuel) by regions of Ukraine

Source: developed by authors using data from Energy balance of Ukraine (2017) [21].

At the same time, only exports of sunflower oil totaled 5741.7 thousand tons, with a total value of almost 4.3 billion USD with an average cost of 747.3 USD per ton (Table 4).

Table 4: Export of sunflower oil in 2017

\begin{tabular}{|l|c|c|c|c|}
\hline \multirow{2}{*}{ Product name } & \multicolumn{4}{|c|}{ Export } \\
\cline { 2 - 5 } & \multicolumn{2}{|c|}{2016} & \multicolumn{2}{|c|}{2017} \\
\cline { 2 - 5 } & amount & million USD & amount & million USD \\
\hline Sunflower oil, thousand tons & 4838.7 & 3702.4 & 5741.7 & 4290.7 \\
\hline
\end{tabular}

Source: developed by authors using data from Statistical collection «Foreign trade of Ukraine in goods and services» (2017) [22].

The cost of importing 1 ton of diesel was 515 USD/ MT (Table 5) totaling more than 5.4 million tons, but the selling price of diesel fuel was more than $25 \mathrm{UAH} /$ liter (1200 USD/tons).

Table 5: Export-import of diesel fuel in 2017

\begin{tabular}{|c|c|c|c|c|c|c|c|c|}
\hline \multirow[b]{3}{*}{ Product name } & \multicolumn{4}{|c|}{ Export } & \multicolumn{4}{|c|}{ Import } \\
\hline & \multicolumn{2}{|c|}{2016} & \multicolumn{2}{|c|}{2017} & \multicolumn{2}{|c|}{2016} & \multicolumn{2}{|c|}{2017} \\
\hline & 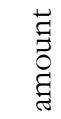 & 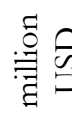 & 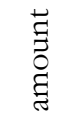 & 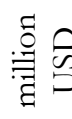 & 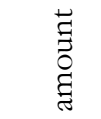 & 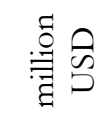 & 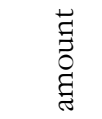 & 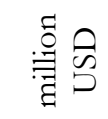 \\
\hline Diesel fuel (gas oil), ths. tons & 0.2 & 0.2 & 0.2 & 0.2 & 5124.9 & 2204.8 & 5422.3 & 2792.2 \\
\hline
\end{tabular}


Source: developed by authors using data from Statistical collection «Foreign trade of Ukraine in goods and services» (2017) [22].

That is, the creation of cooperatives to provide services for the processing of oilseeds for the energy needs of enterprises of small and medium-sized agricultural formations, as well as the provision of livestock sector feeds is economically feasible.

The development of oilseeds processing for the energy needs of the country's economy will enable not only to ensure energy independence, first of all, agriculture itself, but will have the following positive effects:

- ordering industry requires a fairly large number of installations for processing;

- increase of employment rate in rural areas (most of the installations will provide fuel needs primarily in agriculture;

- providing the livestock sector with highly concentrated feed in the form of cake (byproducts in the processing of oilseeds);

- additional production of glycerine for the needs of the perfume industry.

\section{Conclusions}

Consequently, when developing a new agrarian policy, it is necessary to take into account the experience of the EU countries, the transformational processes in the domestic agrarian sector. At the same time, it should have a foreign policy, integration orientation, conditioned by Ukraine's accession to the WTO and preparation for accession to the EU. Moreover, in the process of formation and implementation of the new agricultural policy of Ukraine, attributes, principles and negative tendencies of action in relation to the countries preparing to become members of the European Community, the current Common Agricultural Policy of the EU, which is an independent component of the economic policy of the European Union, should be taken into account.

We are convinced that Ukraine, along with the structuring of state support measures, is right to adopt a state program to support the sale of domestic food products both on the external and internal markets.

Only proper financing by the state will be able to ensure sustainable development of agriculture, raising the living standards of the rural population, protecting the natural environment, preserving natural, labor and productive resources, and increasing the competitiveness of agricultural production.

As a result of the implementation of the ASC development program within Ukraine, the following benefits can be achieved:

- the cost of technological services is reduced because they are provided at a price that does not exceed the cost price;

- the long-term preservation of household products is ensured and the revenue from its sale increases due to the use of seasonal price fluctuations;

- there is an opportunity to additionally attract third-party financial investments under the collective guarantee of the members of the ASC;

- conditions are created for the formation of large-scale batches of products, increase of its qualitative indicators;

- new jobs are created;

- increase of energy independence of Ukraine's economy; 
- GDP growth;

- sustainable development of households is ensured.

\section{References}

1. Sheludko, R. M., Pashchenko, Yu. V., Filimonov, Yu. L. and Bukhalo, O. V. (2019). State support for agricultural sector and its impact to form results indices of the activities at branch enterprises. Financial and credit activity: problems of theory and practice, 2(29): 487-495. https://doi.org/10.18371/fcaptp.v2i29.171995.

2. Sakhno, A., Polishchuk, N., Salkova, I. and Kucher, A. (2019). Impact of credit and investment resources on the productivity of agricultural sector. European Journal of Sustainable Development, 8(2): 235-245. https://doi.org/10.14207/ejsd.2019.v8n2p335.

3. Lebid, S. V. (2015). The current state of financial support of enterprises of agroindustrial complex of Vinnitsa region. Economy, finance, management: topical issues of science and practice, 3: 39-47.

4. Kirieieva, E. A., Pryshliak, N. V., Shamanska, O. I., Salkova, I. Yu. and Kucher, A. V. (2019). Strategic priorities and financial support of Ukrainian agricultural sector development. International Journal of Ecological Economics and Statistics, 40(2): 25-37.

5. Makarenko, I., Serpeninova, Yu. and Pogorila, K. (2018). Institutional support for sustainable development financing in the light of the multistakeholder approach. Agricultural and Resource Economics: International Scientific E-Journal, 4(2): 85-96. Available at: http://are-journal.com.

6. Prokopchuk, O. and Gorbachova, I. (2018). System of institutional and investment support of rural areas development in the USA. Agricultural and Resource Economics: International Scientific E-Journal, 4(2): 115-128. Available at: http://are-journal.com.

7. Yatsiv, I., Khirivskyi, R., Pasichnyk, T., Petryshyn, L. and Kucher, L. (2019). Assessment of the efficiency of resource potential employment by the communities of Lviv region of Ukraine. European Journal of Sustainable Development, 8(2): 165-176. https://doi.org/10.14207/ejsd.2019.v8n2p165.

8. Samarets, N. and Nuzhna, S. (2018). The modern contribution of the basic categories of producers to Ukrainian agrarian production. Agricultural and Resource Economics: International Scientific E-Journal, 4(4): 52-71. Available at: http://are-journal.com.

9. Tanklevska, N. and Miroshnichenko, V. (2019). Theoretical basis of managing of enterprises' financial potential on the basis of anti-crisis management. Agricultural and Resource Economics: International Scientific E-Journal, 5(2): 51-61. Available at: http://are-journal.com.

10. Budnik, O. (2018). Theoretical and methodological bases of the cooperative marketing in agribusiness. Agricultural and Resource Economics: International Scientific E-Journal, 4(4): 85-98. Available at: http://are-journal.com.

11. Osadchuk, Ju. (2017). Effectiveness of the government regulation of the system of financial support for the development of consumer cooperation. Agricultural and Resource Economics: International Scientific E-Journal, 3(3): 90-102. Available at: http://are-journal.com.

12. Popovich, T. M. (2008). Organizational and economic mechanism of regulation of the consumer goods market. Abstract of Ph. D. dissertation. Ternopil National Economic University.

13. Brink, L. (2010). A Billion Dollars a Day: The Economics and Politics of Agricultural Subsidies. European Review of Agricultural Economics, 37(1): 119-121. https://doi.org/10.1093/erae/jbq002.

14. Omotilewa, O. J., Ricker-Gilbert, J. and Herbert, J. (2019). Ainembabazi Subsidies for Agricultural Technology Adoption: Evidence from a Randomized Experiment with Improved Grain Storage Bags in Uganda. American Journal of Agricultural Economics, 101(3): 753-772. https://doi.org/10.1093/ajae/aay108.

15. Yuandong, G., Tao, W., Wen, Y. and Xiaohua, W. (2013). A spatial econometric study on effects of fiscal and financial supports for agriculture in China. Agricultural Economics - Czech, 59: 315-332. https://doi.org/10.17221/126/2012-AGRICECON.

16. Czyzewski, B. and Smedzik-Ambrozy, K. (2017). The regional structure of the CAP subsidies and the factor productivity in agriculture in the EU 28. Agricultural Economics - Czech, 63: 149-163. https://doi.org/10.17221/302/2015-AGRICECON. 
17. Pechrová, M. (2015). Impact of the Rural Development Programme Subsidies on the farms' inefficiency and efficiency. Agricultural Economics - Czech, 61: 197-204. https://doi.org/10.17221/110/2014AGRICECON.

18. Náglová, Z., Šimpachová Pechrová, M. (2019). Subsidies and technical efficiency of Czech food processing industry. Agricultural Economics - Czech, 65: 151-159. https://doi.org/10.17221/234/2018-AGRICECON.

19. Ministry of Agrarian Policy and Food of Ukraine (2018). Government Support to Agriculture: Governmental Programs 2018. Available at: http://dotacii.minagro.gov.ua.

20. Ministry of Agrarian Policy and Food of Ukraine (2018). Agribusiness Development Programs. Available at: http://minagro.gov.ua.

21. State Statistics Department of Ukraine (2017). Energy balance of Ukraine for 2017. Available at: http://www.ukrstat.gov.ua.

22. State Statistics Department of Ukraine (2017). Statistical collection «Foreign trade of Ukraine in goods and services» for 2017 year. Available at: http://www.ukrstat.gov.ua.

23. Department of agro-industrial development of the state administration. (2018). Official site of the Department of Agro-Industrial Development of the State Administration. Available at: http://www.vin.gov.ua.

24. Vinnytsia Regional Association of Local Self-Government Bodies (2019). Official site of the Vinnytsia Regional Association of Local Self-Government Bodies. Available at: http://sg.vn.ua/news/selyanski-gospodarstva-osnova-rozvytku-gromad.

25. Agrarian Union of Ukraine (2018). Official site of the Agrarian Union of Ukraine. Available at: www.auu.org.ua/uk/publications/web/226.

26. Government of Ukraine (2018). The Concept of the State Target Development Program. Available at: https://www.kmu.gov.ua/npas/248907971.

27. The Cabinet of Ministers of Ukraine (2017). On Approval of the Procedure for Using the Funds Envisaged in the State Budget for Partial Compensation for the Cost of Agricultural Machinery and Equipment, Special Grain Carriages, Equipment for the Production of Bioethanol and Electricity from Biomass, Purchased from Domestic Producers. Resolution of the Cabinet of Ministers of Ukraine dated March 1, 2017 No. 130. Available at: https://zakon.rada.gov.ua/go/130-2017-ח.

28. The Cabinet of Ministers of Ukraine (2018). On Amendments to the Procedure for Using the Funds Envisaged in the State Budget for Financial Support of Measures in the Agro-Industrial Complex by Reducing Lending. Resolution of the Cabinet of Ministers of Ukraine dated February 7, 2018, No. 254. Available at: https://zakon.rada.gov.ua/go/254-2018-п.

29. Government of Ukraine (1997). The Law of Ukraine «On Agricultural Cooperation». Vidomosti of the Verkhovna Rada of Ukraine, 39: 261. 